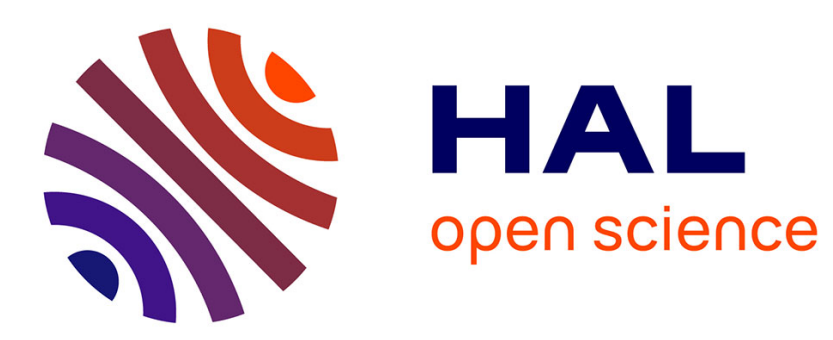

\title{
Short-run and long-run marginal costs of joint products in linear programming
}

\author{
Axel Pierru, Denis Babusiaux
}

\section{To cite this version:}

Axel Pierru, Denis Babusiaux. Short-run and long-run marginal costs of joint products in linear programming: Cahiers de l'Economie, Série Recherche, n 68. 2008. hal-02469431

\section{HAL Id: hal-02469431 \\ https://hal-ifp.archives-ouvertes.fr/hal-02469431}

Preprint submitted on 6 Feb 2020

HAL is a multi-disciplinary open access archive for the deposit and dissemination of scientific research documents, whether they are published or not. The documents may come from teaching and research institutions in France or abroad, or from public or private research centers.
L'archive ouverte pluridisciplinaire HAL, est destinée au dépôt et à la diffusion de documents scientifiques de niveau recherche, publiés ou non, émanant des établissements d'enseignement et de recherche français ou étrangers, des laboratoires publics ou privés. 
INSTITUT FRANÇAIS DU PÉTROLE (IFP)

ÉCOLE DU PÉTROLE ET DES MOTEURS

Centre Économie et Gestion

228-232 avenue Napoléon Bonaparte

92852 RUEIL-MALMAISON CEDEX

\title{
Short-run and long-run marginal costs of joint products in linear programming
}

\author{
Axel PIERRU \\ Denis BABUSIAUX
}

June 2008

Les cahiers de l'économie - $n^{\circ} 68$

Série Recherche

axel.pierru@ifp.fr

denis.babusiaux@numericable.fr

La collection "Les cahiers de l'économie" a pour objectif de présenter des travaux réalisés à l'IFP et à l'École du pétrole et des moteurs, travaux de recherche ou notes de synthèse en économie, finance et gestion. La forme peut être encore provisoire, afin de susciter des échanges de points de vue sur les sujets abordés.

Les opinions émises dans les textes publiés dans cette collection doivent être considérées comme propres à leurs auteurs et ne reflètent pas nécessairement le point de vue de l'IFP ou de l'École du pétrole et des moteurs.

Pour toute information sur le contenu, prière de contacter directement l'auteur ; pour toute information complémentaire prière de contacter le Centre Économie et Gestion, Tél. 0147526425 


\begin{abstract}
In standard microeconomic theory, short-run and long-run marginal costs are equal for production equipment with adjusted capacity. When the production of joint products from interdependent equipment is modeled with a linear program, as in oil refining, this equality is no longer verified. The short-run marginal cost then takes on a left-hand value and a right-hand value which generally differ from the long-run marginal cost. In this article, we demonstrate and interpret the relationship existing between long-run marginal cost and short-run marginal costs for a given finished product. That relationship is simply expressed as a function of marginal capacity adjustments (determined in the long run) and marginal values of capacities (determined in the short run).
\end{abstract}

JEL classification numbers: D20, C61

Keywords: microeconomics, marginal cost, linear programming, energy economics. 


\section{Introduction}

\subsection{The standard microeconomic theory}

When one considers an activity involving the production of a single product, microeconomic theory tells us that with adjusted capacity, short-run and long-run marginal costs are equal under certain conditions. To take a specific example, consider a construction project for a facility of which the size (i.e. the production capacity) needs to be determined. We assume that this size can be represented by a continuous variable. We also assume that the annual production cost for a given size, i.e. the short-run annual cost, is a continuous function that can be derived with respect to the quantity of good produced over the year. If the marginal cost begins to increase at a certain level of production, the curves representing the annual cost for facilities of various sizes generally take the shape of those drawn by the dashed lines on the first graph of Figure 1. The curve representing the long-run annual cost is then the envelope curve (shown by a solid line) of the short-run cost curves. The second graph of Figure 1 reveals, in the case of a rising marginal cost over the long run (long dashed lines), the usual shape of average cost curves over the short run (dashed lines) and the long run (solid line), as well as curves representing short-run and long-run marginal cost (it should be noted that marginal cost can decrease over the long-run in the presence of economies of scale). Under the usual conditions of continuity and differentiability, these properties are well known (e.g. see Boîteux 1960).

LAC: long-run average cost; $\mathrm{LMC}$ : long-run marginal cost; $\mathrm{AC}_{\mathrm{k}}$ : short-run average cost with a production facility of size $\mathrm{E}_{\mathrm{k}} ; \mathrm{MC}_{\mathrm{k}}$ : short-run marginal cost with a production facility of size $\mathrm{E}_{\mathrm{k}}$. 


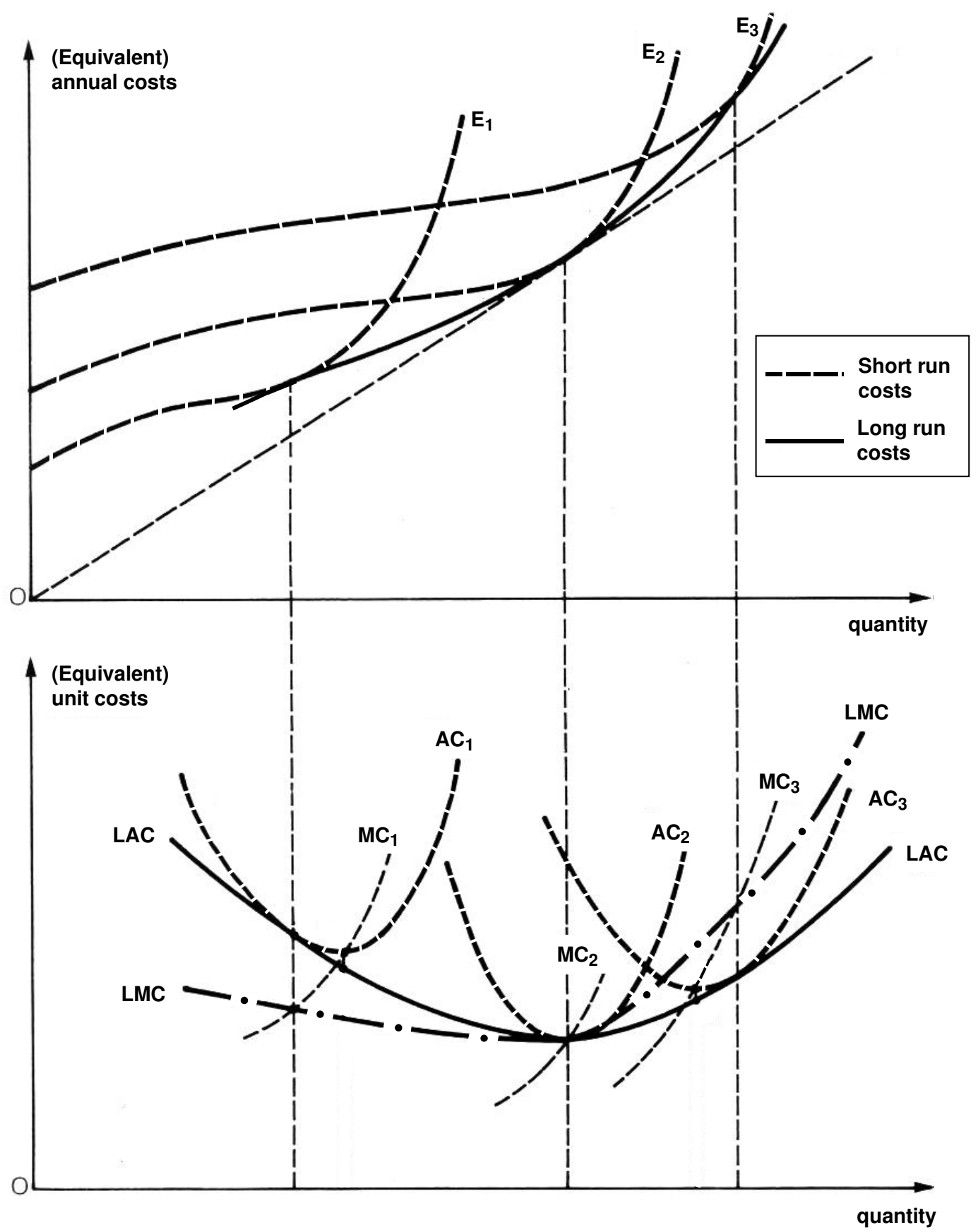

Figure 1. Equality of short-run and long-run marginal costs in standard microeconomic theory. 


\subsection{Purpose of this paper}

In this article, we analyze the case of the production of joint products using various types of interdependent equipment when the production system is modeled via a linear program. Our objective is to establish the relationship between short-run marginal costs and long-run marginal costs in this case.

A first example of such a production system is given by the petroleum refining industry: the main variables represent the quantities of crude oil to be processed and the various flows of intermediate products that characterize the operation of the production units (atmospheric and vacuum distillation, reforming, cracking, etc.) and the composition of the finished products (gasoline, automotive diesel, heating oil, heavy fuel oil, etc.). The main constraints are material-balance equations (which are the most common), product-quality specification equations (sulphur content, gasoline octane number, etc.) and demand equations for finished products (quantities produced, increased in some cases by imported quantities and decreased by exported quantities, greater than or equal to demand). In a short-term management model, there are also capacity equations limiting the feedstock to be processed in each of the units. The economic function only includes operating costs (decreased where applicable by revenues generated by the sale of certain products). In a long-term investment model, variables represent the capacities of the units to be built. If we are dealing with a dynamic model extending over several periods, (linear) investment costs must be associated with these capacity variables, and the economic function is then a total cost discounted over a long period. If we are dealing with a "static" long-term model, the model is representative of a given time horizon. An equivalent annual investment cost is then associated with each capacity variable (initial investment divided by the sum of the discount factors). The economic function to be minimized is then an equivalent annual cost, which results from the sum of the operating cost and equivalent annual investment costs.

Yet another example is supplied by an electrical production system using various types of power plants (nuclear, coal, gas turbine, etc.). The main variables are the powers supplied by the different types of plant for the various hourly/seasonal periods (peak periods during winter weekdays, off-peak periods during summer weekends, etc.). The main constraints are the demand equations expressing the requirement to supply the power demanded for each hourly/seasonal period (and for each outcome if the demand is randomized). Anderson (1972) offers a general description of this type of model.

In practice, the models used for short-term management (particularly in the very short run), are often profit maximization programs, with the price of products being fixed and assumed to be given by the market. It is always possible, however, by taking certain precautions where appropriate, to make the transition from such a profit-maximization formulation to a cost- minimization formulation, subject to the constraint of satisfying a demand for finished products. It is this latter formulation that will be used in the remainder of this article.

We will therefore consider a system composed of a variety of equipment, called production units, producing several joint products. The interdependencies between the units are represented via a linear programming model. We distinguish between a short-term program, for which the capacity of the units is assumed to be fixed, and a long-term program for which a certain number of capacities are variables to be determined. Equivalent annual investment costs are then associated with these variables. For purposes of simplification, we will present the analysis by referring to a static long-term model representative of a given 
time horizon. Over both the short- and long-term, we will consider a cost-minimization problem under demand constraints.

\subsection{Preliminary remarks on marginal costs}

We will begin with some general remarks. Marginal production costs are equal to the dual variables associated with demand constraints, at least if there is no degeneracy. When one varies the demand for a given product, while keeping the demand for other products unchanged, the marginal cost of that product is stable as long as the optimal solution corresponds to the same basic solution. The curve representing the marginal cost as a function of the quantity produced is therefore a stair-step curve. This is true for both the short-run marginal cost and the long-run marginal cost.

Let's consider the optimal solution of a long-term problem, determined by taking into account a fixed demand $b_{i}$ for each product $i$. This solution gives the optimal value for the capacities to be built for the various units. Now set these capacities at their optimal values. The short-term program thus obtained supplies the values for the short-run marginal costs and, in more general terms, allows us to trace the short-run marginal cost of a product as a function of the demand for that product. The short-run marginal cost curve for a product $i$ intersects the long-run marginal cost curve for a demand equal to $b_{i}$, with the capacities consequently being adjusted. This is in line with standard microeconomic theory.

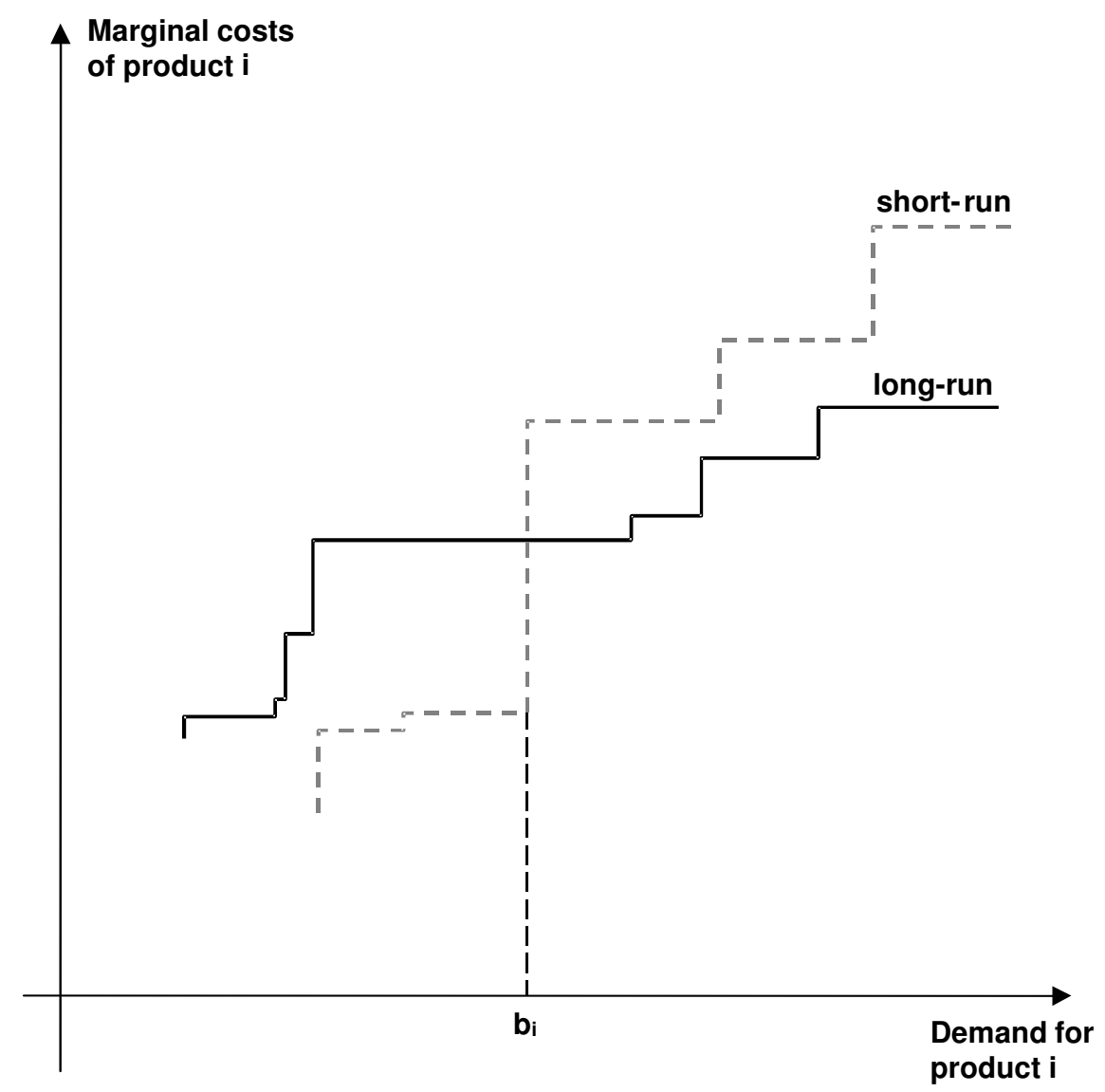

Figure 2. Short-run and long-run marginal costs of product $i$ in linear programming, with capacity adjusted to demand $b_{i}$. 
The distinguishing feature of a production system represented by linear programming is related to the stair-step profile of the curves represented in Figure 2. In general, the long-run marginal cost is stable in the neighborhood of $b_{i}$ while one observes a discontinuity of the short-run marginal cost.

In fact, a long-term problem can be converted into a short-term problem by adding constraints setting the capacities of the units, requiring that the feedstock processed by a unit, or its production, be less than the capacity defined by the optimal solution of the longterm program. These constraints, or at least a certain number of them, are binding at the optimum of the short-term program, which is then degenerate. The objective-function value of the program is no longer differentiable in $b_{i}$. Nevertheless, it has a sub-differential and directional derivatives, which explains the discontinuity of the short-run marginal cost observed at $b_{i}$ in figure 2.

For each finished product, the short-run marginal costs at the left side and right side of the anticipated demand for which the capacity is adjusted are then different and given by components of the dual variables vectors. The literature on degeneracy supplies the criteria for selecting these components in the presence of multiple dual solutions (Aucamp and Steinberg 1982, Gal 1986 and Greenberg 1986). Consequently, we must consider a lefthand marginal cost and a right-hand marginal cost for each finished product.

The objective of this article is to study the relationship between short-run marginal costs and long-run marginal costs. The analysis relies on the marginal values of capacities, equal to the dual variables associated with the capacity constraints introduced in the short-term model. In theory, these variables are negative: in the short run, an increase in available capacity should not generally result in an increase in the operating cost. In order to simplify the presentation of results, we assume throughout this article that the marginal values of capacities are all negative.

\subsection{Breakdown of long-run marginal costs}

We use the breakdown of long-run marginal costs in linear programming proposed by Pierru and Babusiaux (2004): the long-run marginal cost of a given finished product results from the sum of a marginal operating cost and a marginal equivalent investment cost. To obtain it, one simply breaks down the objective function into two elementary economic functions ${ }^{1}$. The marginal operating cost (respectively the marginal equivalent investment cost) is equal to the variation of the elementary function representing the operating cost (respectively the equivalent annual investment cost) for an infinitesimal increase in finished product demand. It has to be noted that the marginal equivalent investment cost is equal to the marginal capacity adjustment times the equivalent annual investment cost per unit of installed capacity.

We will adopt this breakdown with the comment that the equivalent annual investment cost taken into account can result from the sum of the investments in the various units whose

\footnotetext{
${ }^{1}$ With each elementary objective function these authors associate a vector composed of "elementary dual variables"; we will not review the method for breaking down long-run marginal costs here.
} 
capacities are to be optimized. In addition to the operating cost, we will therefore associate an elementary function with each capacity variable. The long-run marginal cost of a product can therefore be broken down into a marginal operating cost and as many marginal equivalent investment costs as there are capacity variables. To eliminate any ambiguity, we specify that for a given finished product the term "marginal operating cost" always refers in this article to a change in the operating cost determined in the long-term model.

The following section introduces the mathematical formulation of the model and the notations used. The results are then presented in the form of propositions. For reasons of clarity, in section 3, we first state and prove the propositions when the model only includes a single capacity variable. We then state and prove those pertaining to the general case in section 4 .

\section{Notations and mathematical formulation of the model}

To illustrate the problem under study, we will consider a static long-term linearprogramming model and the corresponding short-term linear-programming model. The long-term model is used to define the optimal capacities to be built to meet a demand vector $b$ and provides the long-run marginal cost of each finished product, as well as its breakdown into marginal operating cost and marginal equivalent investment costs. The short-term model determines the optimal production program for demand $b$, assuming that capacities are set at the values defined by the long-term model. This short-term model is used to calculate the marginal values of the capacities, as well as the short-run marginal costs (on the left-hand and right-hand of demand $b_{i}$ ) for each finished product $i$. Although the problem studied relates to a linear programming model, we will adopt a formulation that takes its inspiration from the lagrangian duality (which facilitates the formal application of the envelope theorem).

\subsection{Long-term model}

We consider a capacity variable and a feedstock variable for each equipment. A feedstock variable has to be smaller or equal to the corresponding capacity variable (plus a possibly preexisting capacity). With this formulation, the operating cost (associated with the feedstock variable) can be distinguished from the equivalent annual investment cost (associated with the capacity variable) in the objective function.

We adopt the following notations, considering that the long-term problem includes $\mathrm{m}$ capacity variables:

$b$ : vector formed from the demanded quantities of $n$ finished products (the quantity of product $i$ demanded is notated $b_{i}$ );

$x$ : vector of size $q$ formed from the variables which appear in both long-run and short-run primal problems;

$x_{f}$ : subvector of $x$ whose components are the m feedstock variables;

$k=\left(k_{1}, k_{2}, \ldots, k_{m}\right)$ : vector formed from the $m$ capacity variables in the long-term problem;

$(x, k)$ thus represents the entire set of variables of the long-term problem; 
$e=\left(e_{1}, e_{2}, \ldots, e_{m}\right):$ vector formed from the equivalent annual investment costs per unit of installed capacity, building $k_{p}(p \in\{1,2, \ldots, m\})$ involves an equivalent annual investment cost equal to $e_{p} k_{p}$;

The long-term problem is written as follows:

$$
\begin{aligned}
& \operatorname{Min}\langle v, x\rangle+\langle e, k\rangle \\
& \text { s.t. }\left\{\begin{array}{l}
x \in X \\
A x=b \\
x_{f}-k \leq c
\end{array}\right.
\end{aligned}
$$

Where: $\mathrm{A}$ is an $n \times q$ matrix, $A x=b$ represents the set of demand constraints; $X$ is a closed convex set defined as the intersection of linear constraints (equalities and inequalities), corresponding to material balance equations, product-quality specifications, requirements on the signs of variables $\ldots c$ is a vector whose components are the preexisting capacities of the $m$ types of equipment considered; $v$ is a vector of size $q$ whose components are the unit costs associated with the variables in $x ;\langle.,$.$\rangle denotes the inner$ product of two vectors.

The value of this long-term problem, considered as a function of the demand for finished products, is notated $V(b)$. We assume that the optimal solution is non-degenerate; the basic solution is thus unchanged in the neighborhood of $b . V(b)$ is therefore continuously derivable. We will let $l_{i}(b)$ represent the long-run marginal cost of the product $i$ : $l_{i}(b)=\frac{\partial V}{\partial b_{i}}(b)$. It is equal to the dual variable associated with the demand constraint for that product.

The value of $k$ at the optimum of the long-term problem is denoted $\hat{k}(b)$, with $\hat{k}(b)=\left(\hat{k}_{1}(b), \hat{k}_{2}(b), \ldots, \hat{k}_{m}(b)\right)$. A change in the demand for finished product $i$ requires a marginal capacity adjustment equal to $\frac{\partial \hat{k}_{p}}{\partial b_{i}}$ in order for the $p^{\text {th }}$ capacity to remain adjusted. This marginal capacity adjustment generates a marginal equivalent investment cost equal to $e_{p} \frac{\partial \hat{k}_{p}}{\partial b_{i}}$

\subsection{Short-term model}

The short-term problem, derived from the long-term problem introduced in the previous subsection, is written as follows: 


$$
\begin{aligned}
& \operatorname{Min}\langle v, x\rangle \\
& \text { s.t. }\left\{\begin{array}{l}
x \in X \\
A x=b \\
x_{f} \leq c+\hat{k}(b)
\end{array}\right.
\end{aligned}
$$

We introduce two vectors of dual variables, associated with two sets of constraints in this short-term problem:

$y=\left(y_{1}, y_{2}, \ldots, y_{n}\right)$ vector formed from the dual variables associated with the demand constraints in the short-term problem (where $y_{i}(i \in\{1,2, \ldots, n\})$ is the dual variable associated with the demand constraint for product $i)$;

$u=\left(u_{1}, u_{2}, \ldots, u_{m}\right)$ : vector formed from the dual variables associated with capacity constraints in the short-run (where $u_{p}(p \in\{1,2, \ldots, m\})$ is the dual variable associated with the $p^{\text {th }}$-capacity constraint).

\subsection{Construction of a "short-run cost function with continuously-adjusted capacity"}

Let $W$ be a function correctly defined in a neighborhood of $b$, representing the value of the short-term program when the capacity is always adjusted. $W$ is equal to $V$ (the long-term and short-term problems have the same optimal solution) less the sum of the equivalent annual investment costs:

$$
W=V-\sum_{p=1}^{m} e_{p} \hat{k}_{p}
$$

$W$, which we will call a "short-run cost function with continuously-adjusted capacity", is everywhere equal to the part of the objective function representing operating costs in the long-term program (i.e. the elementary function associated with operating costs). As $W$ is equal to a difference of differentiable functions (assuming that the long-term solution is non-degenerate), $W$ is itself differentiable in $b$. This comment is particularly important for the proofs of the propositions stated in the article.

\subsection{Lagrangian formulation of the problem}

Where $L=\langle v, x\rangle+\langle y, b-A x\rangle+\left\langle u, x_{f}-c-\hat{k}(b)\right\rangle$ denotes the usual Lagrangian constructed from the short-term program, we have:

$$
W(b)=\max _{y, u \geq 0} \min _{x \in X} L(x, y, u, \hat{k}(b), b)
$$

If we set $L(\bar{x}(y, u), y, u, \hat{k}(b), b)=\min _{x \in X} L(x, y, u, \hat{k}(b), b)$, the equation (2) can be rewritten as follows:

$$
W(b)=\max _{y, u \geq 0} L(\bar{x}(y, u), y, u, \hat{k}(b), b)
$$


Let $Y^{*}(b)$ denote the set of solutions $(y, u)$ of the short-term dual program:

$$
Y^{*}(b)=\underset{y, u \geq 0}{\operatorname{Arg} \max }\left(\min _{x \in X} L(x, y, u, \hat{k}(b), b)\right)
$$

$Y^{*}(b)$ is not a singleton due to the degeneracy of the optimal solution (there are several vectors of dual variables and thus several saddle points). $L$ thus possesses partial directional derivatives in $b_{i}$ and each product has two short-run marginal costs. Where $s_{i}^{+}(b)$ denotes the right-hand short-run marginal cost of the product $i$ and $s_{i}^{-}(b)$ its lefthand short-run marginal cost, we encounter the traditional results of the degeneracy (see for instance Milgrom and Segal 2002):

$$
\begin{aligned}
& s_{i}^{+}(b)=\frac{\partial^{+} L}{\partial b_{i}}=\max _{(y, u) \in Y^{*}(b)} \frac{\partial L}{\partial b_{i}}=\max _{(y, u) \in Y^{*}(b)} y_{i} \\
& s_{i}^{-}(b)=\frac{\partial^{-} L}{\partial b_{i}}=\min _{(y, u) \in Y^{*}(b)} \frac{\partial L}{\partial b_{i}}=\min _{(y, u) \in Y^{*}(b)} y_{i}
\end{aligned}
$$

Similarly, if the vector $\mu$ (with $\mu=\left(\mu_{1}, \mu_{2}, \ldots, \mu_{m}\right)$ ) is formed from the marginal values of the capacities in the short run, as defined in the introduction, we have:

$\mu_{p}=\frac{\partial^{-} L}{\partial \hat{k}_{p}}=\min _{(y, u) \in Y^{*}(b)} \frac{\partial L}{\partial \hat{k}_{p}}=\min _{(y, u) \in Y^{*}(b)}-u_{p}=-\max _{(y, u) \in Y^{*}(b)} u_{p}$

where $\mu_{p}(p \in\{1,2, \ldots, m\})$ : marginal value of the $p^{\text {th }}$ capacity set at $c_{p}+\hat{k}_{p}(b)$ in the short-term problem.

\section{Specific case: model with a single capacity variable}

\subsection{Statement of the propositions}

Our results can be summarized by the following propositions, stated for a given finished product $i$ :

(i) the left-hand short-run marginal cost is equal to the marginal operating cost if the marginal capacity adjustment is positive;

(ii) the right-hand short-run marginal cost is equal to the marginal operating cost if the marginal capacity adjustment is negative;

(iiia) the difference between the two short-run marginal costs is equal to the absolute value of the product of the marginal value of capacity by the marginal capacity adjustment;

(iiib) if one considers two distinct finished products: the ratio of the differences between right-hand short-run marginal cost and left-hand short-run marginal cost is equal to the absolute value of the ratio of the marginal equivalent investment costs (or, which amounts to the same thing, to the absolute value of the ratio of the marginal capacity adjustments). 
These propositions are proved in the following section. Proposition (iiib) follows directly from (iiia). We would remark that the first two propositions are quite intuitive, since, in the long-term model, the marginal operating cost represents the change in the operating cost when an additional ton of the product in question must be produced.

\subsection{Proof of the propositions}

The long-term model includes only a single capacity variable: $k, \hat{k}(b), e$ and $\mu$ are therefore scalars. A change in the demand for finished product $i$ requires a marginal capacity adjustment equal to $\frac{\partial \hat{k}}{\partial b_{i}}=\frac{\partial^{+} \hat{k}}{\partial b_{i}}=\frac{\partial^{-} \hat{k}}{\partial b_{i}}$ in order for the capacity to remain adjusted. The marginal equivalent investment cost is equal to $e \frac{\partial \hat{k}}{\partial b_{i}}$.

As $W$ is differentiable in $b$, its left-hand and right-hand partial derivatives with respect to $b_{i}$ are equal. We will distinguish the two following cases.

\subsubsection{A product with a positive marginal capacity adjustment}

Consider a finished product $i$ for which the marginal capacity adjustment is positive, i.e., $\frac{\partial \hat{k}}{\partial b_{i}} \geq 0$. By applying the envelope theorem to the equation (3) we obtain the two following equations:

$$
\frac{\partial W}{\partial b_{i}}(b)=\frac{\partial^{+} W}{\partial b_{i}}(b)=\frac{\partial^{+} L}{\partial b_{i}}+\frac{\partial^{-} L}{\partial \hat{k}} \frac{\partial^{+} \hat{k}}{\partial b_{i}}=s_{i}^{+}(b)+\frac{\partial^{-} L}{\partial \hat{k}} \frac{\partial \hat{k}}{\partial b_{i}}
$$

$$
\frac{\partial W}{\partial b_{i}}(b)=\frac{\partial^{-} W}{\partial b_{i}}(b)=\frac{\partial^{-} L}{\partial b_{i}}+\frac{\partial^{+} L}{\partial \hat{k}} \frac{\partial^{-} \hat{k}}{\partial b_{i}}=s_{i}^{-}(b)+\frac{\partial^{+} L}{\partial \hat{k}} \frac{\partial \hat{k}}{\partial b_{i}}
$$

Equation (4) can be analyzed as follows: since $\frac{\partial \hat{k}}{\partial b_{i}} \geq 0$, an increase in demand for product $i$ keeps binding the capacity constraint in the short-run, with $\frac{\partial^{-} L}{\partial \hat{k}}=\mu$. Conversely, in equation (5), a decrease in demand for product $i$ results in the capacity constraint no longer being binding, and consequently $\frac{\partial^{+} L}{\partial \hat{k}}=0$. Equations (4) and (5) thus give us:

$$
\frac{\partial W}{\partial b_{i}}(b)=s_{i}^{+}(b)+\mu \frac{\partial \hat{k}}{\partial b_{i}}=s_{i}^{-}(b)
$$


Furthermore, by differentiating equation (1) we obtain:

$$
\frac{\partial W}{\partial b_{i}}(b)=\frac{\partial V}{\partial b_{i}}(b)-e \frac{\partial \hat{k}}{\partial b_{i}}(b)=l_{i}(b)-e \frac{\partial \hat{k}}{\partial b_{i}}(b)
$$

Equation (7) indicates that $\frac{\partial W}{\partial b_{i}}(b)$ is equal to the marginal operating cost.

By combining equations (6) and (7), we obtain:

$$
l_{i}(b)=s_{i}^{+}(b)+(\mu+e) \frac{\partial \hat{k}}{\partial b_{i}^{+}}=s_{i}^{-}(b)+e \frac{\partial \hat{k}}{\partial b_{i}^{-}}
$$

This result is crucial since it explains the transition from the long-run marginal cost to shortrun marginal costs. And finally:

$$
s_{i}^{+}(b)=l_{i}(b)-(\mu+e) \frac{\partial \hat{k}}{\partial b_{i}}=\left(l_{i}(b)-e \frac{\partial \hat{k}}{\partial b_{i}}\right)-\mu \frac{\partial \hat{k}}{\partial b_{i}}
$$

$$
s_{i}^{-}(b)=l_{i}(b)-e \frac{\partial \hat{k}}{\partial b_{i}}
$$

Equation (9) proves the proposition (i): the left-hand short-run marginal cost is equal to the marginal operating cost (i.e., the long-run marginal cost less the marginal equivalent investment cost).

\subsubsection{A product with a negative marginal capacity adjustment}

Now consider a product $j$ for which the marginal capacity adjustment is negative, i.e., $\frac{\partial \hat{k}}{\partial b_{j}} \leq 0$. An increase in the demand for this product results in the capacity constraint being no longer binding in the short run. Conversely, a decrease in this demand would keep this constraint binding. By applying the envelope theorem, we thus obtain:

$$
\begin{gathered}
\frac{\partial W}{\partial b_{j}}(b)=\frac{\partial^{+} W}{\partial b_{j}}(b)=\frac{\partial^{+} L}{\partial b_{j}}+\frac{\partial^{+} L}{\partial \hat{k}} \frac{\partial^{+} \hat{k}}{\partial b_{j}}=s_{j}^{+}(b)+\frac{\partial^{+} L}{\partial \hat{k}} \frac{\partial \hat{k}}{\partial b_{j}} \\
\frac{\partial W}{\partial b_{j}}(b)=\frac{\partial^{-} W}{\partial b_{j}}(b)=\frac{\partial^{-} L}{\partial b_{j}}+\frac{\partial^{-} L}{\partial \hat{k}} \frac{\partial^{-} \hat{k}}{\partial b_{j}}=s_{j}^{-}(b)+\frac{\partial^{-} L}{\partial \hat{k}} \frac{\partial \hat{k}}{\partial b_{j}}
\end{gathered}
$$


By proceeding as in the earlier instance, we finally obtain via equations (7), (10) and (11):

$$
\begin{aligned}
& s_{j}^{+}(b)=l_{j}(b)-e \frac{\partial \hat{k}}{\partial b_{j}} \\
& s_{j}^{-}(b)=l_{j}(b)-(\mu+e) \frac{\partial \hat{k}}{\partial b_{j}}=\left(l_{j}(b)-e \frac{\partial \hat{k}}{\partial b_{j}}\right)-\mu \frac{\partial \hat{k}}{\partial b_{j}}
\end{aligned}
$$

Equation (12) proves the proposition (ii). Equations (8), (9), (12) and (13) are summarized in Table 1.

Table 1: short-run marginal costs

\begin{tabular}{|l|c|c|}
\cline { 2 - 3 } \multicolumn{1}{c|}{} & Left-hand short-run marginal cost & $\begin{array}{c}\text { Right-hand short-run marginal } \\
\text { cost }\end{array}$ \\
\hline marginal equivalent investment cost $\geq 0$ & marginal operating cost & marginal operating cost $+\mid \begin{array}{c}\text { marginal value of capacity } \\
\times \text { marginal capacity adjustment }\end{array}$ \\
\hline marginal equivalent investment cost $\leq 0$ & marginal operating cost $-\mid \begin{array}{c}\text { marginal value of capacity } \\
\times \text { marginal capacity adjustment }\end{array}$ & marginal operating cost \\
\hline
\end{tabular}

For any finished product $i$, the proposition (iiia) is immediately deduced from the preceding equations:

$$
s_{i}^{+}(b)-s_{i}^{-}(b)=\left|\mu \frac{\partial \hat{k}}{\partial b_{i}}\right|
$$

Which can be written:

$$
\begin{aligned}
& \text { right-hand short-run marginal cost }- \text { left-hand short-run marginal cost } \\
& \quad=\mid \text { marginal value of capacity } \times \text { marginal capacity adjustment } \mid
\end{aligned}
$$

For a given finished product, the difference between the two short-run marginal costs is therefore proportional to the marginal equivalent investment cost assigned to this product.

We do in fact find that for any product $i: s_{i}^{+}(b) \geq s_{i}^{-}(b)$.

If we consider two finished products $i$ and $j$, we have:

$$
\frac{s_{i}^{+}(b)-s_{i}^{-}(b)}{s_{j}^{+}(b)-s_{j}^{-}(b)}=\left|\frac{\partial \hat{k} / \partial b_{i}}{\partial \hat{k} / \partial b_{j}}\right|=\left|\frac{\text { marginal equivalent investment cost of product } i}{\text { marginal equivalent investment cost of product } j}\right|
$$

This equation proves the proposition (iiib): the ratio of the differences of short-run marginal costs is equal to the absolute value of the ratio of the marginal equivalent investment costs. 


\section{General case: model with several capacity variables}

\subsection{Statement of the propositions}

Let us consider a given finished product $i$. Let $Z_{i}^{+}$denote the set of capacity variables for which the marginal equivalent investment cost associated with product $i$ is positive. $Z_{i}^{-}$ then denotes the set of capacity variables for which the marginal equivalent investment cost associated with product $i$ is negative. We can state the following propositions:

(j) the left-hand short-run marginal cost is given by the following formula: marginal operating cost $-\sum_{Z_{i}}$ (marginal capacity adjustment $\times$ marginal value of capacity)

(jj) the right-hand short-run marginal cost is given by the following formula: marginal operating cost $-\sum_{Z_{+}^{+}}$(marginal capacity adjustment $\times$marginal value of capacity)

(jjj) the difference between the two short-run marginal costs is equal to:

$$
\sum_{Z_{i}+Z_{i}^{+}} \mid \text {marginal capacity adjustment } \times \text { marginal value of capacity } \mid
$$

\subsection{Proof of the propositions}

The long-run marginal cost of a given finished product $i$ is broken down into the sum of $m+1$ terms:

- the marginal operating cost,

- $m$ marginal equivalent investment costs.

Without loss of generality, we will assume that the marginal equivalent investment costs corresponding to the first $z$ capacity variables are positive and that those corresponding to the other $m-z$ are negative. In other terms, the set of the first $z$ capacity variables forms $Z_{i}^{+}$. The marginal capacity adjustments are as follows:

$$
\begin{aligned}
& \frac{\partial \hat{k}_{p}}{\partial b_{i}}(b) \geq 0 \quad \text { for } p \in\{1,2, \ldots, z\} \\
& \frac{\partial \hat{k}_{p}}{\partial b_{i}}(b) \leq 0 \text { for } p \in\{z+1, z+2, \ldots, m\}
\end{aligned}
$$

Following the same line of reasoning as was used in the specific instance of a single capacity constraint, we obtain:

$$
\frac{\partial W}{\partial b_{i}}(b)=s_{i}^{+}(b)+\sum_{p=1}^{z} \mu_{p} \frac{\partial \hat{k}_{p}}{\partial b_{i}}=s_{i}^{-}(b)+\sum_{p=z+1}^{m} \mu_{p} \frac{\partial \hat{k}_{p}}{\partial b_{i}}
$$

Moreover, by differentiating equation (1) we have:

$$
\frac{\partial W}{\partial b_{i}}(b)=l_{i}(b)-\sum_{p=1}^{m} e_{p} \frac{\partial \hat{k}_{p}}{\partial b_{i}}(b)
$$


As previously, $\frac{\partial W}{\partial b_{i}}(b)$ is equal to the marginal operating cost.

By combining equations (14) and (15), we obtain:

$$
\begin{aligned}
s_{i}^{-}(b)= & \left(l_{i}(b)-\sum_{p=1}^{m} e_{p} \frac{\partial \hat{k}_{p}}{\partial b_{i}}\right)-\sum_{p=z+1}^{m} \mu_{p} \frac{\partial \hat{k}_{p}}{\partial b_{i}} \\
& (16) \\
s_{i}^{+}(b)= & \left(l_{i}(b)-\sum_{p=1}^{m} e_{p} \frac{\partial \hat{k}_{p}}{\partial b_{i}}\right)-\sum_{p=1}^{z} \mu_{p} \frac{\partial \hat{k}_{p}}{\partial b_{i}}
\end{aligned}
$$

Equations (16) and (17) prove the propositions (j) and (jj). By combining these two equations, we obtain:

$$
s_{i}^{+}(b)-s_{i}^{-}(b)=\sum_{p=z+1}^{m} \mu_{p} \frac{\partial \hat{k}_{p}}{\partial b_{i}}-\sum_{p=1}^{z} \mu_{p} \frac{\partial \hat{k}_{p}}{\partial b_{i}}
$$

Or (assuming that the marginal values of capacities are negative):

$$
s_{i}^{+}(b)-s_{i}^{-}(b)=\sum_{p=1}^{m}\left|\mu_{p} \frac{\partial \hat{k}_{p}}{\partial b_{i}}\right|
$$

Equation (18) proves the proposition (jjj).

\section{Conclusion: economic interpretation}

In conclusion, we will emphasize the economic interpretation of the results obtained, formulated by the propositions in section II. We will first consider the specific case of a model with only one capacity variable.

Take the example of a finished product for which the marginal equivalent investment cost is positive. The right-hand short-run marginal cost of this product is given by the right-hand term of equation (8) which represents the sum of two terms. The first term is equal to the marginal operating cost (i.e. the cost of the optimal change over the long run in inputs which remain variable over the short run). The second term is equal to the marginal capacity adjustment (i.e. the additional capacity required in the long run to produce an additional unit of the finished product) multiplied by the marginal value of the capacity in the short run. Since one cannot have this additional capacity in the short term, a cost premium, equal to this additional capacity multiplied by the marginal value of the capacity, is generated. Conversely, the left-hand short-run marginal cost of this product is just equal to the marginal operating cost. In fact, in the long run, increasing the production of the finished product, to the point of meeting anticipated demand, requires having additional 
capacity. In the short run, however, this additional capacity is available (since the capacity was set in relation to anticipated demand). As a result, no cost premium is generated.

A similar analysis can be made for a product with a negative marginal equivalent investment cost. Thus, the left-hand short-run marginal cost is less than the marginal operating cost since, in the short run, producing more entails a relaxation of the capacity constraint thereby saving cost.

It is interesting to note that in the specific case in which the absolute value of the marginal value of capacity is equal to the equivalent annual investment cost per unit of installed capacity, each finished product has a short-run marginal cost equal to the long-run marginal cost (the right-hand cost for products for which the marginal equivalent investment cost is positive, and the left-hand cost for the others).

This type of analysis is also applicable in the general case of models with several capacity variables. The marginal operating cost is then increased by the sum of additional costs incurred (for the right-hand short-run marginal cost) or decreased by the sum of costs saved (for the left-hand short-run marginal cost).

In addition to their theoretical interest, these results, which complement traditional microeconomic theory, can be quite useful in practice. There are numerous constraints and variables in the field of oil refining. Apart from extreme situations, the number of steps comprising marginal cost curves is such that the curves are "smoothed" and are not far removed from those of traditional microeconomic theory. However, for runs with highlybinding capacities, the "jumps" in marginal costs can be significant. This is all the more true for peak demand in the electricity sector, where power cannot be stockpiled. A better comprehension of marginal costs should thus serve as a valuable aid for market power analysis. 


\section{References}

Anderson D., (1972), Models for determining least-cost investments in electricity supply, Bell Journal of Economics and Management Science, 6, pp. 267-299.

Aucamp D. C. and D. I. Steinberg, (1982), The computation of shadow prices in linear programming, Journal of the Operational Research Society, 33, pp. 557-565.

Boiteux M., (1960), Peak-load pricing, The Journal of Business, 33, pp. 157-179.

Gal T., (1986), Shadow prices and sensitivity analysis in linear programming under degeneracy, OR Spektrum, 8, pp. 59-71.

Greenberg H. J., (1986), An analysis of degeneracy, Naval Research Logistics Quarterly, 33, pp. 635-655.

Milgrom P. and I. Segal, (2002), Envelope theorems for arbitrary choice sets, Econometrica, 70, pp. 583-601.

Palmer K.H., N.K. Boudwin, H.A. Patton, A.J. Rowland, J.D. Sammes and D.M. Smith, (1984), A model-management framework for mathematical programming - An Exxon Monograph, New York, John Wiley \& Sons.

Pierru A. and D. Babusiaux, (2004), Breaking down a long-run marginal cost of an LP investment model into a marginal operating cost and a marginal equivalent investment cost, The Engineering Economist, 49, pp. 307-326. 


\section{Déjà parus}

CEG-1. D. PERRUCHET, J.-P. CUEILLE,

Compagnies pétrolières internationales : intégration verticale et niveau de risque.

Novembre 1990

CEG-2. C. BARRET, P. CHOLLET,

Canadian gas exports: modeling a market in disequilibrium.

Juin 1990

CEG-3. J.-P. FAVENNEC, V. PREVOT,

Raffinage et environnement.

Janvier 1991

CEG-4. D. BABUSIAUX,

Note sur le choix des investissements en présence de rationnement du capital.

Janvier 1990

CEG-5. J.-L. KARNIK,

Les résultats financiers des sociétés de raffinage distribution en France 1978-89.

Mars 1991

\section{CEG-6. I. CADORET, P. RENOU,}

Élasticités et substitutions énergétiques : difficultés méthodologiques.

Avril 1991

\section{CEG-7. I. CADORET, J.-L. KARNIK,}

Modélisation de la demande de gaz naturel dans le secteur domestique : France, Italie, Royaume-Uni 19781989.

Juillet 1991

CEG-8. J.-M. BREUIL,

Émissions de SO2 dans l'industrie française : une approche technico-économique.

Septembre 1991

CEG-9. A. FAUVEAU, P. CHOLLET, F. LANTZ,

Changements structurels dans un modèle économétrique de demande de carburant.

Octobre 1991

CEG-10. P. RENOU,

Modélisation des substitutions énergétiques dans les pays de l'OCDE.

Décembre 1991

CEG-11. E. DELAFOSSE,

Marchés gaziers du Sud-Est asiatique : évolutions et enseignements.

Juin 1992

CEG-12. F. LANTZ, C. IOANNIDIS,

Analysis of the French gasoline market since the deregulation of prices.

Juillet 1992

CEG-13. K. FAID,

Analysis of the American oil futures market.

Décembre 1992

CEG-14. S. NACHET,

La réglementation internationale pour la prévention et l'indemnisation des pollutions maritimes par les hydrocarbures.

Mars 1993 
CEG-15. J.-L. KARNIK, R. BAKER, D. PERRUCHET,

Les compagnies pétrolières : 1973-1993, vingt ans après.

Juillet 1993

CEG-16. N. ALBA-SAUNAL,

Environnement et élasticités de substitution dans l'industrie ; méthodes et interrogations pour l'avenir.

Septembre 1993

CEG-17. E. DELAFOSSE,

Pays en développement et enjeux gaziers : prendre en compte les contraintes d'accès aux ressources locales.

Octobre 1993

CEG-18. J.P. FAVENNEC, D. BABUSIAUX,*

L'industrie du raffinage dans le Golfe arabe, en Asie et en Europe : comparaison et interdépendance.

Octobre 1993

CEG-19. S. FURLAN,

L'apport de la théorie économique à la définition d'externalité.

Juin 1994

CEG-20. M. CADREN,

Analyse économétrique de l'intégration européenne des produits pétroliers : le marché du diesel en Allemagne et en France.

Novembre 1994

CEG-21. J.L. KARNIK, J. MASSERON,*

L'impact du progrès technique sur l'industrie du pétrole.

Janvier 1995

CEG-22. J.P. FAVENNEC, D. BABUSIAUX,

L'avenir de l'industrie du raffinage.

Janvier 1995

CEG- 23. D. BABUSIAUX, S. YAFIL, *

Relations entre taux de rentabilité interne et taux de rendement comptable.

Mai 1995

CEG-24. D. BABUSIAUX, J. JAYLET,*

Calculs de rentabilité et mode de financement des investissements, vers une nouvelle méthode?

Juin 1996

CEG-25. J.P. CUEILLE, J. MASSERON,*

Coûts de production des énergies fossiles : situation actuelle et perspectives.

Juillet 1996

CEG-26. J.P. CUEILLE, E. JOURDAIN,

Réductions des externalités : impacts du progrès technique et de l'amélioration de l'efficacité énergétique.

Janvier 1997

CEG-27. J.P. CUEILLE, E. DOS SANTOS,

Approche évolutionniste de la compétitivité des activités amont de la filière pétrolière dans une perspective de long terme.

Février 1997

CEG-28. C. BAUDOUIN, J.P. FAVENNEC,

Marges et perspectives du raffinage.

Avril 1997 
CEG-29. P. COUSSY, S. FURLAN, E. JOURDAIN, G. LANDRIEU, J.V. SPADARO, A. RABL, Tentative d'évaluation monétaire des coûts externes liés à la pollution automobile : difficultés méthodologiques et étude de cas.

Février 1998

\section{CEG-30. J.P. INDJEHAGOPIAN, F. LANTZ, V. SIMON,}

Dynamique des prix sur le marché des fiouls domestiques en Europe.

Octobre 1998

CEG-31. A. PIERRU, A. MAURO,

Actions et obligations : des options qui s'ignorent.

Janvier 1999

CEG-32. V. LEPEZ, G. MANDONNET,

Problèmes de robustesse dans l'estimation des réserves ultimes de pétrole conventionnel.

Mars 1999

CEG-33. J. P. FAVENNEC, P. COPINSCHI,

L'amont pétrolier en Afrique de l'Ouest, état des lieux

Octobre 1999

CEG-34. D. BABUSIAUX,

Mondialisation et formes de concurrence sur les grands marchés de matières premières énergétiques : le pétrole.

Novembre 1999

CEG-35. D. RILEY,

The Euro

Février 2000

CEG-36. et 36bis. D. BABUSIAUX, A. PIERRU,

Calculs de rentabilité et mode de financement des projets d'investissements : propositions méthodologiques.

Avril 2000 et septembre 2000

CEG-37. P. ALBA, O. RECH,

Peut-on améliorer les prévisions énergétiques?

Mai 2000

CEG-38. J.P. FAVENNEC, D. BABUSIAUX,

Quel futur pour le prix du brut?

Septembre 2000

ECO-39. S. JUAN, F. LANTZ,

La mise en œuvre des techniques de Bootstrap pour la prévision économétrique : application à l'industrie automobile

Novembre 2000

ECO-40. A. PIERRU, D. BABUSIAUX,

Coût du capital et étude de rentabilité d'investissement : une formulation unique de l'ensemble des méthodes. Novembre 2000

ECO-41. D. BABUSIAUX,

Les émissions de $\mathrm{CO} 2$ en raffinerie et leur affectation aux différents produits finis

Décembre 2000

ECO-42. D. BABUSIAUX,

Éléments pour l'analyse des évolutions des prix du brut.

Décembre 2000 
ECO-43. P. COPINSCHI,

Stratégie des acteurs sur la scène pétrolière africaine (golfe de Guinée).

Janvier 2001

ECO-44. V. LEPEZ,

Modélisation de la distribution de la taille des champs d'un système pétrolier, LogNormale ou Fractale ? Une approche unificatrice.

Janvier 2001

ECO-45. S. BARREAU,

Innovations et stratégie de croissance externe : Le cas des entreprises parapétrolières.

Juin 2001

ECO-46. J.P. CUEILLE,

Les groupes pétroliers en 2000 : analyse de leur situation financière.*

Septembre 2001

ECO-47. T. CAVATORTA,

La libéralisation du secteur électrique de l'Union européenne et son impact sur la nouvelle organisation électrique française

Décembre 2001

ECO-48. P. ALBA, O. RECH,

Contribution à l'élaboration des scénarios énergétiques.

Décembre 2001

ECO-49. A. PIERRU,*

Extension d'un théorème de dualité en programmation linéaire : Application à la décomposition de coûts marginaux de long terme.

Avril 2002

ECO-50. T. CAVATORTA,

La seconde phase de libéralisation des marchés du gaz de l'Union européenne : enjeux et risques pour le secteur gazier français.

Novembre 2002

ECO-51. J.P. CUEILLE, L. DE CASTRO PINTO COUTHINO, J. F. DE MIGUEL RODRÍGUEZ,*

Les principales compagnies pétrolières indépendantes américaines : caractéristiques et résultats récents.

Novembre 2002

ECO-52. J.P. FAVENNEC,

Géopolitique du pétrole au début du XXI ${ }^{\mathrm{e}}$ siècle

Janvier 2003

ECO-53. V. RODRIGUEZ-PADILLA,

avec la collaboration de T. CAVATORTA et J.P. FAVENNEC,*

L'ouverture de l'exploration et de la production de gaz naturel au Mexique, libéralisme ou nationalisme Janvier 2003

ECO-54. T. CAVATORTA, M. SCHENCKERY,

Les majors pétroliers vers le multi énergies : mythe ou réalité ?

Juin 2003

ECO-55. P.R. BAUQUIS,*

Quelles énergies pour les transports au XXI ${ }^{e}$ siècle?

Janvier 2004 
ECO-56. A. PIERRU, D. BABUSIAUX,

Evaluation de projets d'investissement par une firme multinationale : généralisation du concept de coût moyen pondéré du capital et conséquences sur la valeur de la firme.

Février 2004

ECO-57. N. BRET-ROUZAUT, M. THOM,

Technology Strategy in the Upstream Petroleum Supply Chain.

Mars 2005

ECO-58. A. PIERRU,

Allocating the $\mathrm{CO}_{2}$ emissions of an oil refinery with Aumann-Shapley prices.

June 2005

ECO-59. F. LESCAROUX,

Les conséquences économiques de la hausse du prix du pétrole.*

Mai 2006

\section{ECO-60. F. LESCAROUX, O. RECH}

L'origine des disparités de demande de carburant dans l'espace et le temps : l'effet de la saturation de l'équipement en automobiles sur l'élasticité revenu.

Juin 2006

ECO-61. C. I. VASQUEZ JOSSE, A. NEUMANN,

Transatlantic Natural Gas Price and Oil Price Relationships - An Empirical Analysis.

Septembre 2006

ECO-62. E. HACHE,

Une analyse de la stratégie des compagnies pétrolières internationales entre 1999 et 2004.

Juillet 2006

ECO-63 F. BERNARD, A. PRIEUR,

Biofuel market and carbon modeling to evaluate French biofuel policy.

Octobre 2006

ECO-64. E. HACHE,

Que font les compagnies pétrolières internationales de leurs profits?

Janvier 2007

ECO-65. A. PIERRU,

A note on the valuation of subsidized Loans - Working paper

Janvier 2007

ECO-66. D. BABUSIAUX, P. R. BAUQUIS,*

Que penser de la raréfaction des ressources pétrolières et de l'évolution du prix du brut ?

Septembre 2007

ECO-67. F. LESCAROUX,

Car ownership in relation to income distribution and consumers's spending decisions.

Novembre 2007

\footnotetext{
* une version anglaise de cet article est disponible sur demande
} 